\title{
Educating for Cultural Awareness
}

\author{
Kristina Urbonienè \\ Šiauliai "Sauletekis" Gymnasium, Šiauliai, Lithuania
}

\begin{abstract}
Schools nowadays are keenly aware of the need to develop their students as global citizens. Project work is a useful tool that helps develop creativity, self-confidence, and intercultural competence. International projects give students the opportunity to be educated as culturally rich, emotionally strong, initiative, and tolerant personalities. International projects provide students with the opportunity to value and share a study of their local traditions with others. At the same time as developing their own value of their community project work also allows them to develop their understanding of the traditions of others. In the article the ideas on participating in an international Comenius project are shared and the benefits of such activities are highlighted.
\end{abstract}

Keywords: cultural awareness, educating, language teaching, international projects

\section{Introduction}

"Cultural competence is defined as a set of congruent behaviors, attitudes, and policies that come together in a system, agency, or among professionals and enables that system, agency, or those professionals to work effectively in cross-cultural situations" (Cross, Bazron, Dennis, \& Isaacs, 1989; Isaacs \& Benjamin, 1991). Cultural awareness can be explained as knowledge or understanding of culture or cultural situation which entails understanding of how a person's culture may inform their values, behaviour, beliefs, and basic assumptions. Cultural awareness recognizes that we are formed by our cultural background and helps to explore cultural issues with our recipients more sensitively. "Cultural awareness becomes central when we have to interact with people from other cultures. People see, interpret and evaluate things in a different ways. What is considered an appropriate behavior in one culture is frequently inappropriate in another one" (Quappe \& Cantatore, 2005). People's values, beliefs, and behavior can differ enormously depending on the culture they belong to. Thus, it is essential to identify individual needs and preferences and remember that no individual can be reduced to a set of cultural norms. Knowing your own culture is vital and if a person cannot see his own culture, he will not be able to see the differences in values between cultures. By recognizing the different influences from his background, the individual will be able to recognize the different influences in their partners' background and will be more likely to engage in a kind and warm relationship. Schools in the 21 st century are keenly aware of the need to develop their students as global citizens. The duty of teachers, school authorities, and parents should definitely be to search for ways that make learning more meaningful for the students using comprehensive practice such as project work. Basically, project work is one of the tools that help develop creativity, self-confidence, and intercultural competence. "Intercultural competence can also be enhanced through a range of intercultural experiences, for example by attending international schools, attending multi-ethnic institutions which have a non-discriminatory environment, or by having extensive contact with

Kristina Urbonienè, master, Social Sciences, Šiauliai “Saulètekis” Gymnasium. 
people from other countries" (Pascarella, Edison, Nora, Hagedorn, \& Terenzini, 1996; Straffon, 2003; Zhai \& Scheer, 2004). "Intercultural competence may also be related to holding a more global, international perspective and lower levels of ethnocentrism" (Caligiuri, Jacobs, \& Farr, 2000). International projects give students the opportunity to value and share a study of their local traditions with others. At the same time, as developing their own value of their community, project work also allows them to develop their understanding of the traditions of others. International projects provide students with the possibility of knowing their own culture better (becoming aware of their own cultural and historical background), help to break down barriers to effective communication and collaboration, improve linguistic competences, and develop a range of cross-curricular skills (IT, research, essay writing, presenting, etc.). Students of "Sauletekis" Gymnasium in Šiauliai, Lithuania, were involved in an international Comenius project "Cultural and Gastronomic Rendez-Vous" which was funded by the European Commission. At the heart of this project was coming together of College La Petite Camargue (France, the coordinating school) with its partner schools from Lithuania, Italy, Portugal, Spain, and Germany to produce an e-cultural/cook magazine, a blog and a multilingual European cook book (printed version) which could act as cultural guides to our modern Europe. The principal aim of this project was to develop amongst our students the idea of active European citizenship through sharing and exchange of work based on culinary traditions and local, regional, and national heritage. This project also aided the linguistic development of students. It was a cross-curricular study focusing on Family traditions, Festivals, History, Art, Music, Modern Foreign Languages, and Citizenship. An ID card of the region and the country was produced on the basis of four seasons. Winter stood for family traditions, Spring for the land and the local products, Summer for travelling and cultural exchange, and Autumn back to school-for everyday cuisine. All the texts were written in English and the mother tongue. Students - ambassadors were chosen to represent their peers to participate in the visits and help to share their work. This European cultural and gastronomic brotherhood has worked together for two years and during this period four meetings took place, in which the cultural sharing and exchanging came to its peak.

\section{Project Meetings}

The encounters started in Germany, where the cold Winter season was the theme, but the gastronomic and cultural warmth were ever present. During the project meeting in Karlsruhe, the programme included an official reception at the City Hall, guided tours around the school, visiting Christmas markets, an excursion to Heidelberg city, baking Christmas cookies at school. Students - ambassadors presented their countries, schools, students, and teachers had an opportunity to try traditional snacks from different countries.

Then there was the Spring meeting in Italy, where the past of Latin culture lives on in a still fertile and culturally rich soil. In the second project meeting in Pomezia project presentations on spring dishes and traditions were held at the City Hall, an excursion to the local history and agricultural museum was organized; students could also attend a unique fish auction in Terracina. They enjoyed visits to Rome and a local cheese factory farm market.

The flavours of the Summer season were celebrated in Spain, where the art of Flamenco filled our souls. Students made presentations on summer traditions and food; everyone could try snacks from partner countries. All the participants were invited to the reception at Leganes City Hall. We spent a wonderful day in Toledo, watched the Flamenco Christmas Show, and had a guided tour of Madrid. During the farewell lunch the partners were taught traditional Lithuanian, Spanish, and Portuguese dances. It all had its epilogue in the 
marvelous South of France, where the Autumn season perfectly defined the nostalgia of something coming to an end, but where the joy was even greater for the experiences shared.

When meeting in Montpellier, students attended lessons, had a guided tour of the school, tried traditional snacks, had a walking tour of the village Lansargues, and were officially welcomed by the mayor. Many games about Europe, including project material from the e-book and involving all the students were organized. Also, a walking city tour in groups was held where students had to accomplish tasks on places of interest in Montpellier. Project students and teachers were given a chance to visit a medieval city Aigues Mortes and local salt marshes. Students enjoyed different activities in the local horse ranch and a village festival with games around horses and bulls. The most important moment of the project-a final fiesta took place and the final product of the project $-\mathrm{a}$ cook book was presented.

\section{E-blog and a Cook Book}

When in their countries the students of each school worked on and researched traditions and typical recipes in order to share them with the help of the national blogs and later of the e-book with the partner countries. Thus they learned a lot about their own country and they had to make sure that they had the necessary linguistic skills in the common language English in order to communicate with their partners. Each country had a blog which students and teachers used as a working platform. The best results from these blogs were added to a shared blog that formed the basis for the print version of the cook book which was the highlight and the main result and the most obvious common goal of students and teachers. Therefore, it was necessary to learn about European copyright laws, to make sure of a professional layout and to find designers and printing companies that would enable the number of prints of 1,000 copies. Finally, the 107-page cook book was printed and presented to the public at the final meeting in France. It contained recipes and traditions from all countries, which were ordered by season. The cook book is useful not only in terms of finding recipes of delicious dishes but also showing cultural differences and teaching six different languages. The website and the book can serve as cultural and culinary guides to six European countries. A glossary with the most commonly used products or seasons in six languages is presented at the very end of the book.

\section{Other Project Activities}

In addition to four successful meetings in different countries, each school had to perform some certain activities at the local level. This depended on each country's possibilities and local peculiarities. The main topic still remained regional and local traditions, research on culinary heritage as means to understanding their own identity. In Lithuania, we organized a very funny and enjoyable event at our Gymnasium. It was trying spring dishes and voting for the best spring recipe. Participants of the project prepared some traditional spring dishes; others could try and vote for the most delicious dish or the one which could represent our country best. Then, an event to celebrate Comenius Week was held at our Gymnasium. An information pole with the distances and ways of how to reach partner institutions was made and presented to all the students of our Gymnasium. Also, an educational trip to local cheese factory was organized where students were introduced to different ways of producing cheese in Lithuania. Students could try five types of cheese and choose the most delicious. A final fiesta called "We eat what we are and we are what we eat" took place in our school canteen where parents, school administration, and students could have a wonderful time helping themselves to dishes from six different countries (prepared by students or their families) and seeing the final product of the project-a cook book. 


\section{The Benefits of the Project}

The intercultural exchange between students allowed them to develop a concept of European citizenship. The originality of this project came from the theme that project partners had chosen: students examined their own local traditions (in all their facets, music, food, family, legends, etc.) and shared these across the partnership. They studied their own regions as a means to understanding our "modern Europe". When choosing the recipes on the blogs, they got to know democratic tools. At the meetings in Germany, Italy, Spain, and France the students stayed with host families and the visits of sights, common meals and cooking gave them a direct impression of the traditions and dishes that they had experienced via the blogs before. The teachers had the opportunity to get to know different educational concepts and they could transfer some of these concepts to the everyday practice in their own countries. The students realised the cultural diversity in Europe when working on the different dishes and traditions and they found new friends when visiting other countries, which was not based on race, culture, or religion. They saw themselves as foreigners who were warmly welcomed by their hosts, which changed their own view on foreigners profoundly. Students have developed their cultural knowledge and a much broader notion of modern European citizenship, have improved their ICT competences, and were encouraged to be creative and innovative through the editing of the e-magazine. They were also involved in peer assessment of each other's work; each country has shown how local and national cultural history is linked to the culinary traditions.

\section{Conclusion}

"Cultural awareness is defined as the process of conducting self-examination of one's own biases towards other cultures and the in-depth exploration of one's cultural and professional background" (Campinha-Bacote, 2002). I believe that teachers should take up international projects which develop cultural knowledge and a much broader notion of modern European citizenship. Students become aware of their own cultural background and this helps to understand that all people in the world are different and equal at the same time. Only by understanding their own culture can students understand that the behaviour and beliefs of people within each culture can vary considerably. This helps students to be aware of judging other people's behaviour and beliefs according to the standards of your own culture.

\section{References}

Caligiuri, P. M., Jacobs, R. R., \& Farr, J. L. (2000). The attitudinal and behavioral openness scale: Scale development and construct validation. International Journal of Intercultural Relations, 24, 27-46.

Campinha-Bacote, J. (2002). The process of cultural competence in the delivery of healthcare services: A model of care. Retrieved from http://www.culture-advantage.com/awarenesspage1.html

Cross, T., Bazron, B., Dennis, K., \& Isaacs, M. (1989). Towards a culturally competent system of care, volume I. Washington, D.C.: Georgetown University Child Development Center, CASSP Technical Assistance Center.

Isaacs, M., \& Benjamin, M. (1991). Towards a culturally competent system of care, volume II, programs which utilize culturally competent principles. Washington, D.C.: Georgetown University Child Development Center, CASSP Technical Assistance Center.

Pascarella, E. T., Edison, M., Nora, A., Hagedorn, L. S., \& Terenzini, P. T. (1996). Influences on students' openness to diversity and challenge in the first year of college. The Journal of Higher Education, 67, 174-195.

Quappe, S., \& Cantatore, G. (2005). What is cultural awareness, anyway? How do I build it? Retrieved from http://www.culturosity.com/articles/whatisculturalawareness.htm

Straffon, D. A. (2003). Assessing the intercultural sensitivity of high school students attending an international school. International Journal of Intercultural Relations, 27, 487-501.

Zhai, L., \& Scheer, S. D. (2004). Global perspectives and attitudes toward cultural diversity among summer agriculture students at the Ohio State University. Journal of Agricultural Education, 45, 39-51. 